\title{
Head Computed Tomography Images of HIV/AIDS Patients with Suspected Cerebral Toxoplasmosis in Dr. Soetomo General Hospital Surabaya
}

\author{
Ria Wibawani ${ }^{1}$, Bambang Soeprijanto ${ }^{2 *}$, Widiana Ferriastuti², Erwin A. Triono ${ }^{3}$ \\ ${ }^{1}$ Faculty of Medicine, Universitas Airlangga, Surabaya, Indonesia \\ ${ }^{2}$ Department of Radiology, Faculty of Medicine, Universitas Airlangga, Surabaya, Indonesia - Dr. Soetomo General Hospital \\ Surabaya, Indonesia \\ ${ }^{3}$ Department of Internal Medicine, Faculty of Medicine, Universitas Airlangga, Surabaya, Indonesia - Dr. Soetomo General \\ Hospital Surabaya, Indonesia
}

\section{A R T I C L E I N F O}

\section{Article history:}

Received 21 May 2019

Received in revised form 18 June 2019

Accepted 25 June 2019

Available online 30 June 2019

Keywords:

HIV/AIDS

Head CT,

Cerebral Toxoplasmosis.

*) Corresponding author:

bambangsoeprijanto@yahoo.com

\begin{abstract}
A B S T RA C T
Introduction: Toxoplasma gondii is an intracellular pathogenic parasite with the majority of coinfections occurring in HIV/AIDS patients. This study assesses the head computed tomography (CT) images of cerebral toxoplasmosis in patients with HIV/AIDS.

Methods: This study was a cross-sectional design using head CT images of 35 HIV/AIDS patients with suspected cerebral toxoplasmosis. Variables include lesion type, location, size, CD4 count, and therapeutic result with anti-cerebral toxoplasmosis. All data analysed descriptively.

Results: From total 110,35 patients met the inclusion criteria. 24 patients $(68.6 \%)$ were male and $11(31.4 \%)$ female, average age, was 36.1 .8 patients $(22.3 \%)$ had lesions in cortical, 31 patients $(88.6 \%)$ had $<1 \mathrm{~cm}$ lesion. Single lesions mainly calcified and found in the right centrum semiovale while multiple lesions were subcortical. A hypodense lesion with rim or nodular contrast enhancement is found in $75 \%$ of patients with CD4 $>200$ in contrast to slight rim contrast enhancement and perifocal edema in patients with CD4 $<200.20$ patients $(57.4 \%)$ had improved condition after anti-toxoplasmosis therapy.

Conclusion: Cerebral toxoplasmosis lesions in HIV/AIDS patients have various types of imaging findings, mostly multiple, with most frequent location being cortical and diameter $<1 \mathrm{~cm}$. Total recovery is achieved in the majority of patients with therapy.
\end{abstract}

\section{Introduction}

Toxoplasmosis is an infection caused by Toxoplasma gondii, an obligate intracellular protozoan parasite. ${ }^{1}$ Thirty percent of the world population have positive antibodies against $T$. gondii. ${ }^{2}$ Toxoplasmosis frequently occurs in patients with HIV. In recent years, the number of HIV patients in developing countries, including Indonesia, has sharply increased.

HIV is a neurotropic virus which crosses the blood-brain barrier. HIV-associated central nervous system (CNS) diseases are categorized into 3 types: opportunistic infections, neoplasms, and vascular diseases. A meta-analysis by Wang et al. (2017) which included 34 countries showed that patients with HIV have a high incidence of $T$. gondii infection. ${ }^{2} \mathrm{HIV} /$ AIDS can promote reactivation of $T$. gondii infection due to weak immune condition. ${ }^{3}$

HIV and T. gondii interact and worsen a patient's condition. Under the immunodeficient condition, especially when CD4 count $<100$ cells $/ \mathrm{mm}^{3}$, T. gondii is activated. The highest risk of activation is in patients with CD4 $<50$ cells $/ \mathrm{mm}^{3}$.

Diagnosis of cerebral toxoplasmosis can be made by neuroradiologic modalities, brain biopsy, empirical trials, as well as microbiologic, serologic, and PCR examinations. The gold standard for definitive diagnosis is a histopathological examination of brain biopsy or tachyzoite found in brain tissue. ${ }^{4}$

Imaging modalities that can be used in the diagnosis of cerebral toxoplasmosis include Magnetic Resonance Imaging (MRI) and Computed Tomography (CT). Although MRI is more sensitive, its availability and usage in health centers in Indonesia are still limited due to its high cost. Therefore, CT is still the preferred choice. ${ }^{5}$ CT images can show single, multiple hypodense, or hypointense lesions in white matter and basal ganglia. The most common lesion found is multiple ring enhancement. ${ }^{6}$ The lesion is 
usually accompanied by edema which can be fatal. Cerebral toxoplasmosis is the most common HIV coinfection. Diagnosis is made using both clinical and neuroradiologic approach. ${ }^{3}$

From the explanation above, there is still not much data on head CT findings of suspected cerebral toxoplasmosis in Indonesia, therefore we conducted head CT profile study of HIV/AIDS patients with suspected cerebral toxoplasmosis.

\section{Methods}

\section{Subject determinations}

This study is a cross-sectional study conducted at Dr. Soetomo General Hospital Surabaya from January 2018 - January 2019. Subjects of this study include all HIV/AIDS patients with suspected cerebral toxoplasmosis who had undergone CT examinations from January 2018 - January 2019. Inclusion criteria were a diagnosis of HIV, had undergone head CT as well as empirical anti-toxoplasmosis therapy. Patients whose medical record was missing or incomplete died, or discharged at own request was excluded. We collected data regarding sex, age, signs \& symptoms, CD4 count, and therapeutic response.

\section{Imaging parameters}

Patients were examined using a 128-slice CT Aquilion CX, TSX-101A (Toshiba Medical Systems Corp., Japan). All head CT images were reviewed by one neuroradiology consultants. Gathered data were analyzed based on lesion type, size, and location. Lesion type is defined as an abnormal change in brain parenchymal structure seen as a characteristic finding that is useful in diagnosing suspected cerebral toxoplasmosis. Lesion size is categorized into single or multiple and hypodense without contrast enhancement, hypodense with slight ring enhancement, ring enhancement, calcification, eccentric target sign, or perifocal edema. Location is defined as the distribution of area with abnormal changes in brain parenchyma due to $T$. gondii infection and is either cortical, corticalsubcortical, or corticomedullary junction, basal ganglia, thalamus, cerebellum, or periventricular. All descriptive data analyses were performed using SPSS for windows version 24.0 (IBM Corp.).

\section{Results}

From total of $110 \mathrm{HIV} / \mathrm{AIDS}$ patients that were admitted with suspected cerebral toxoplasmosis, there were 35 who met the inclusion criteria. 24 patients $(68.6 \%)$ were male with average age 36.1 years old. (Table 1)

CD4 count data are available in 16 patients. Twelve (75.0\%) patients have CD $4<200$ with a mean of 54.26 cells $/ \mathrm{mm} 3$ while the remaining $4(25.0 \%)$ have CD4 $>200$ with a mean of 489.25 cells $/ \mathrm{mm} 3$. Based on CD4 count data, most subjects in all categories (CD4 $<200$, CD4 $>200$, and no CD4 data) were male $(83.3 \%, 75.0 \%$, and $57.9 \%$ respectively).
Based on the location (Table 3), 4 patients $(33.3 \%)$ with CD4 $<200$ had lesions at corticomedullary junction and basal ganglia. On the other hand, 3 patients (75\%) CD4 > 200 had in subcortical while in those without CD4 data, 12 $(63.2 \%)$ are cortical-subcortical. $31(88.6 \%)$ patients have small lesion (diameter $<1 \mathrm{~cm}$ ), it was noticed in all patients with CD $4<200$.Large lesions are found in $1(25.0 \%)$ patient with CD4 $>200$ and $3(15.8 \%)$ patients without CD4 data.

In terms of post-therapeutic results, 10 (58.3\%) patients with CD4 $<200,3(75.0 \%)$ patients with CD4 > 200, and $10(52.6 \%)$ patients without CD4 data achieved complete recovery. The remaining patients have either partial recovery or irreversible condition. Most patients $(80 \%)$ with complete recovery have lesion diameter $<1 \mathrm{~cm}$ but the same applies to patients with partial recovery or irreversible condition $(88.9 \%)$. None of the patients with lesion diameter $>1 \mathrm{~cm}$ achieved complete recovery. Lesions located at cortical, cerebellum, centrum semiovale, internal capsule, and periventricular mostly achieved complete recovery with anti-toxoplasmosis while those at the subcortical, corticomedullary junction, basal ganglia, thalamus, cortical-subcortical, corona radiata, external capsule, and insular lobe achieved either partial recovery or irreversible condition.

Problems in the head CT images are also identified. $7(20.0 \%)$ have leptomeningeal enhancement and other $7(20.0 \%)$ have gyral enhancement at right and left parieto-occipital lobes with dominance at Sylvian fissure and cerebellar tentorium, left fronto-parietal lobe, and both parietotemporal lobes respectively. In patients with CD4 < $200,3(24.9 \%)$ have $\pm 1.17 \mathrm{~cm}$ midline shift to the right with $\pm 0.7 \mathrm{~cm}$ subfalcine herniation and $1(8.3 \%)$ has $\pm 0.58 \mathrm{~cm}$ midline shift to the left. $4(33.3 \%)$ patients with CD4 $<200$ have communicating hydrocephalus and $2(50.0 \%)$ with CD4 > 200 have non-communicating hydrocephalus. Other problems found in patients with $\mathrm{CD} 4<200$ include chronic cerebral infarction at left internal and external capsules as well as irregular left middle cerebral artery (MCA) which point towards vasculitis.

In general, patients with associated problems of midline shift, leptomeningeal and gyral enhancement, hydrocephalus, vasculitis, intracerebral hemorrhage, and infarction only achieved partial recovery.

Comorbidities found in this study are in patients with CD4 $<200$ which include right and left maxillary sinusitis as well as left maxillary, ethmoidal, and sphenoid sinusitis. 
Table 1. Characteristics of HIV/AIDS patients with suspected cerebral toxoplasmosis in Dr. Soetomo General Hospital Surabaya.

\begin{tabular}{clccc}
\hline \multirow{2}{*}{$\begin{array}{c}\text { Patient } \\
\text { Characteristics }\end{array}$} & \multicolumn{3}{c}{ CD4 count (f,\%) } \\
\cline { 3 - 5 } & \multicolumn{2}{c}{$\begin{array}{c}\text { CD4 count } \\
\text { available }(\mathbf{n}=16)\end{array}$} & $\begin{array}{c}\text { CD4 count } \\
\text { unavailable } \\
(\mathbf{n}=19)\end{array}$ \\
\cline { 3 - 4 } Sex & Male & $10(83.3 \%)$ & $3(75.0 \%)$ & $11(57.9 \%)$ \\
& Female & $2(16.7 \%)$ & $1(25.0 \%)$ & $8(42.1 \%)$ \\
Age & Oldest & 25 & 33 & 23 \\
& Youngest & 60 & 39 & 59 \\
& Average & 36 & 37 & 36 \\
\hline
\end{tabular}

Table 2. Lesion types of HIV/AIDS patients with suspected cerebral toxoplasmosis in Dr. Soetomo General Hospital Surabaya.

\begin{tabular}{|c|c|c|c|c|c|c|c|c|}
\hline & \multicolumn{4}{|c|}{ Multiple } & \multicolumn{4}{|c|}{ Single } \\
\hline & \multicolumn{2}{|c|}{$\begin{array}{l}\text { CD4 count } \\
\text { available } \\
(n=16)\end{array}$} & \multirow[t]{2}{*}{$\begin{array}{l}\text { CD4 count } \\
\text { unavailable } \\
(n=19)\end{array}$} & \multirow[t]{2}{*}{$\begin{array}{c}\text { Total } \\
(n=35)\end{array}$} & \multicolumn{2}{|c|}{$\begin{array}{c}\text { CD4 count } \\
\text { available }(n=16\end{array}$} & \multirow[t]{2}{*}{$\begin{array}{l}\text { CD4 count } \\
\text { unavailable } \\
(n=19)\end{array}$} & \multirow[t]{2}{*}{$\begin{array}{r}\text { Total } \\
(n=35)\end{array}$} \\
\hline & $\begin{array}{c}<200 \\
(n=12)\end{array}$ & $\begin{array}{l}>200 \\
(n=4)\end{array}$ & & & $\begin{array}{c}<200 \\
(n=12)\end{array}$ & $\begin{array}{l}>200 \\
(n=4)\end{array}$ & & \\
\hline $\begin{array}{l}\text { Hypodense with } \\
\text { slight rim contrast } \\
\text { enhancement }\end{array}$ & $\begin{array}{c}10 \\
(83.3 \%)\end{array}$ & $\begin{array}{c}2 \\
(50 \%)\end{array}$ & $\begin{array}{c}16 \\
(84.2 \%)\end{array}$ & $\begin{array}{c}28 \\
(80 \%)\end{array}$ & - & - & - & - \\
\hline $\begin{array}{l}\text { Perifocal edema } \\
\text { surrounding lesion }\end{array}$ & $\begin{array}{c}10 \\
(83.3 \%) \\
\end{array}$ & $\begin{array}{c}2 \\
(50 \%) \\
\end{array}$ & $\begin{array}{c}15 \\
(78.9 \%) \\
\end{array}$ & $\begin{array}{c}27 \\
(77.14 \%) \\
\end{array}$ & $\begin{array}{c}1 \\
(8.3 \%) \\
\end{array}$ & - & - & - \\
\hline $\begin{array}{l}\text { Hypodense with rim } \\
\text { contrast } \\
\text { enhancement }\end{array}$ & $\begin{array}{c}6 \\
(50 \%)\end{array}$ & $\begin{array}{c}3 \\
(75 \%)\end{array}$ & $\begin{array}{c}9 \\
(47.4 \%)\end{array}$ & $\begin{array}{c}18 \\
(51.43 \%)\end{array}$ & - & - & - & - \\
\hline $\begin{array}{l}\text { Hypodense with } \\
\text { nodular contrast } \\
\text { enhancement }\end{array}$ & $\begin{array}{c}3 \\
(25 \%)\end{array}$ & $\begin{array}{c}3 \\
(75 \%)\end{array}$ & $\begin{array}{c}3 \\
(15.8 \%)\end{array}$ & $\begin{array}{c}9 \\
(25.71 \%)\end{array}$ & - & - & - & - \\
\hline Eccentric target sign & $\begin{array}{c}3 \\
(25 \%)\end{array}$ & $\begin{array}{c}2 \\
(50 \%)\end{array}$ & $\begin{array}{c}6 \\
(31.6 \%)\end{array}$ & $\begin{array}{c}11 \\
(31.43 \%)\end{array}$ & - & - & - & - \\
\hline $\begin{array}{l}\text { Hypodense with } \\
\text { slight nodular } \\
\text { contrast } \\
\text { enhancement }\end{array}$ & $\begin{array}{c}3 \\
(25 \%)\end{array}$ & - & $\begin{array}{c}4 \\
(21.1 \%)\end{array}$ & $\begin{array}{c}7 \\
(20 \%)\end{array}$ & - & - & - & - \\
\hline Calcification & $\begin{array}{c}2 \\
(16.7 \%)\end{array}$ & $\begin{array}{c}1 \\
(25 \%)\end{array}$ & $\begin{array}{c}0 \\
(0 \%)\end{array}$ & $\begin{array}{c}3 \\
(8.57 \%)\end{array}$ & $\begin{array}{c}1 \\
(8,3 \%)\end{array}$ & - & - & - \\
\hline Brain edema & $\begin{array}{c}2 \\
(16.7 \%)\end{array}$ & $\begin{array}{c}1 \\
(25 \%)\end{array}$ & $\begin{array}{c}2 \\
(10.5 \%)\end{array}$ & $\begin{array}{c}5 \\
(14.29 \%)\end{array}$ & - & - & - & - \\
\hline $\begin{array}{l}\text { Perifocal edema } \\
\text { without contrast } \\
\text { enhancement }\end{array}$ & $\begin{array}{c}2 \\
(16.7 \%)\end{array}$ & $\begin{array}{c}1 \\
(25 \%)\end{array}$ & $\begin{array}{c}3 \\
(15.8 \%)\end{array}$ & $\begin{array}{c}3 \\
(15.8 \%)\end{array}$ & - & - & - & - \\
\hline $\begin{array}{l}\text { Hypodense without } \\
\text { contrast } \\
\text { enhancement }\end{array}$ & $\begin{array}{c}2 \\
(16.7 \%)\end{array}$ & - & $\begin{array}{c}2 \\
(10.5 \%)\end{array}$ & $\begin{array}{c}4 \\
(11.43 \%)\end{array}$ & - & - & - & - \\
\hline
\end{tabular}


Table 4. Therapeutic response of HIV/AIDS patients with suspected cerebral toxoplasmosis in Dr. Soetomo General Hospital Surabaya.

\begin{tabular}{|c|c|c|c|c|c|}
\hline \multicolumn{2}{|c|}{ Therapeutic response } & \multicolumn{3}{|c|}{ CD4 Count (f,\%) } & \multirow{3}{*}{$\begin{array}{c}\text { Total } \\
(n=35)\end{array}$} \\
\hline & & \multicolumn{2}{|c|}{$\begin{array}{l}\text { CD4 count available } \\
\qquad(n=16)\end{array}$} & \multirow[t]{2}{*}{$\begin{array}{l}\text { CD4 count un- } \\
\text { available } \\
(n=19)\end{array}$} & \\
\hline & & $<200(n=12)$ & $>200(n=4)$ & & \\
\hline \multirow[t]{2}{*}{ Recovery } & Complete & $7(58.3 \%)$ & $3(75.0 \%)$ & $10(52.6 \%)$ & $20(57.4 \%)$ \\
\hline & Partial & $3(25.0 \%)$ & - & $1(5.3 \%)$ & $4(11.4 \%)$ \\
\hline \multirow[t]{2}{*}{ No recovery } & Death & $1(8.3 \%)$ & $1(25.0 \%)$ & $7(36.8 \%)$ & $9(25.7 \%)$ \\
\hline & $\begin{array}{l}\text { Irreversible condi- } \\
\text { tion }\end{array}$ & $1(8.3 \%)$ & - & $1(5.3 \%)$ & $2(5.7 \%)$ \\
\hline
\end{tabular}

Table 3. Lesion location of HIV/AIDS patients with suspected cerebral toxoplasmosis in Dr. Soetomo General Hospital Surabaya

\begin{tabular}{|c|c|c|c|c|c|c|c|c|}
\hline \multirow{3}{*}{$\begin{array}{c}\text { Lesson } \\
\text { Location }\end{array}$} & \multicolumn{4}{|c|}{ Multiple } & \multicolumn{4}{|c|}{ Single } \\
\hline & \multicolumn{2}{|c|}{$\begin{array}{l}\text { CD4 count available } \\
\qquad(n=16)\end{array}$} & \multirow[t]{2}{*}{$\begin{array}{l}\text { CD4 count } \\
\text { unavailable } \\
(n=19)\end{array}$} & \multirow[t]{2}{*}{$\begin{array}{c}\text { Total } \\
(n=35)\end{array}$} & \multicolumn{2}{|c|}{$\begin{array}{c}\text { CD4 count } \\
\text { available }(n=16)\end{array}$} & \multirow{2}{*}{$\begin{array}{c}\text { CD4 } \\
\text { count } \\
\text { un- } \\
\text { avail- } \\
\text { able } \\
(n=19)\end{array}$} & \multirow[t]{2}{*}{$\begin{array}{r}\text { Total } \\
(n=35)\end{array}$} \\
\hline & $\begin{array}{c}<200 \\
(n=12)\end{array}$ & $\begin{array}{l}>200 \\
(n=4)\end{array}$ & & & $\begin{array}{l}>200 \\
(n=4)\end{array}$ & $\begin{array}{l}>200 \\
(n=4)\end{array}$ & & \\
\hline $\begin{array}{l}\text { Cortical- } \\
\text { subcortical }\end{array}$ & $2(16.7 \%)$ & $2(50 \%)$ & $12(63.17 \%)$ & $14(40 \%)$ & - & - & - & - \\
\hline Subcortical & $3(25 \%)$ & $3(75 \%)$ & $7(36.84 \%)$ & $12(34.29 \%)$ & - & - & - & - \\
\hline Basal ganglia & $4(33.3 \%)$ & $1(25 \%)$ & $7(36.84 \%)$ & $12(34.29 \%)$ & - & - & - & - \\
\hline Cortical & $3(25 \%)$ & $2(50 \%)$ & $3(15.79 \%)$ & $8(22.29 \%)$ & - & - & - & - \\
\hline Thalamus & $3(25 \%)$ & $2(50 \%)$ & $2(10.52 \%)$ & $7(20 \%)$ & - & - & - & - \\
\hline Internal capsule & - & $1(25 \%)$ & $6(31.59 \%)$ & $7(20 \%)$ & - & - & - & - \\
\hline Cerebellum & $3(25 \%)$ & $1(25 \%)$ & $2(10.5 \%)$ & $6(17.14 \%)$ & - & - & - & - \\
\hline $\begin{array}{l}\text { Centrum } \\
\text { Semiovale }\end{array}$ & $3(25 \%)$ & - & $3(15.79 \%)$ & $6(17.14 \%)$ & $1(8.3 \%)$ & - & - & - \\
\hline $\begin{array}{l}\text { Cortico- } \\
\text { medullary } \\
\text { junction }\end{array}$ & $4(33.3 \%)$ & $1(25 \%)$ & $0(0 \%)$ & $5(14.29 \%)$ & - & - & - & - \\
\hline Periventricular & $1(8.3 \%)$ & - & $0(0 \%)$ & $1(2.86 \%)$ & - & - & - & - \\
\hline Corona Radiata & - & - & $1(5.3 \%)$ & $1(2.86 \%)$ & - & - & - & - \\
\hline External capsule & - & - & $3(15.8 \%)$ & $3(8.57 \%)$ & - & - & - & - \\
\hline Insular Lobe & - & - & $1(5.3 \%)$ & $1(2.86 \%)$ & - & - & - & - \\
\hline
\end{tabular}


Table 5. Comorbidities of HIV/AIDS patients with suspected cerebral toxoplasmosis in Dr. Soetomo General Hospital Surabaya.

\begin{tabular}{|c|c|c|c|c|}
\hline \multirow{3}{*}{ Comorbidities } & \multicolumn{3}{|c|}{ CD4 count (f,\%) } & \multirow{3}{*}{$\begin{array}{c}\text { Total } \\
(n=35)\end{array}$} \\
\hline & \multicolumn{2}{|c|}{$\begin{array}{l}\text { CD4 count available } \\
\qquad(n=16)\end{array}$} & \multirow[t]{2}{*}{$\begin{array}{l}\text { CD4 count } \\
\text { unavailable } \\
(n=19)\end{array}$} & \\
\hline & $<200(\mathrm{n}=12)$ & $>200(n=4)$ & & \\
\hline Right and left maxillary sinusitis & $1(8.3 \%)$ & - & - & $1(2.9 \%)$ \\
\hline Left maxillary sinusitis & $1(8.3 \%)$ & - & - & $1(2.9 \%)$ \\
\hline $\begin{array}{l}\text { Left maxillary, left ethmoidal, left } \\
\text { sphenoidal sinusitis }\end{array}$ & $1(8.3 \%)$ & - & - & $1(2.9 \%)$ \\
\hline $\begin{array}{l}\text { Right and left maxillary, ethmoidal, } \\
\text { and sphenoidal sinusitis }\end{array}$ & $1(8.3 \%)$ & - & - & $1(2.9 \%)$ \\
\hline $\begin{array}{l}\text { Bilateral maxillary, ethmoidal, and } \\
\text { sphenoidal sinusitis }\end{array}$ & - & $1(25.0 \%)$ & - & $1(2.9 \%)$ \\
\hline Left sphenoidal sinusitis & - & $1(25.0 \%)$ & - & $1(2.9 \%)$ \\
\hline $\begin{array}{l}\text { Left sphenoidal and bilateral ethmodial } \\
\text { sinusitis }\end{array}$ & - & $1(25.0 \%)$ & - & $1(2.9 \%)$ \\
\hline $\begin{array}{l}\text { Right and left maxillary, right sphenoi- } \\
\text { dal sinusitis }\end{array}$ & - & - & $1(5.3 \%)$ & $1(2.9 \%)$ \\
\hline Left frontal and left ethmoidal sinusitis & - & - & $1(5.3 \%)$ & $1(2.9 \%)$ \\
\hline $\begin{array}{l}\text { Left maxillary sinus retention cyst and } \\
\text { pansinusitis }\end{array}$ & - & - & $1(5.3 \%)$ & $1(2.9 \%)$ \\
\hline Left maxillary sinusitis & - & - & $2(10.5 \%)$ & $2(5.7 \%)$ \\
\hline Left maxillary, left ethmoidal sinusitis & - & - & $1(5.3 \%)$ & $1(2.9 \%)$ \\
\hline $\begin{array}{l}\text { Right and left frontal and maxillary si- } \\
\text { nusitis, left ethmoidal, left sphenoidal } \\
\text { sinusitus }\end{array}$ & - & - & $1(5.3 \%)$ & $1(2.9 \%)$ \\
\hline
\end{tabular}

\section{Discussion}

This study showed that CD4 levels may differentiate the characteristics of cerebral toxoplasmosis lesions found in head CT images. In CD4 > 200, lesions are mostly hypodense with rim or nodular contrast enhancement found at subcortical. In CD4 $<200$, all lesions found were multiple, the majority are hypodense with slight rim contrast enhancement and perifocal edema surrounding the lesion at corticomedullary junction and basal ganglia.

Head CT is required as the initial neuroimaging modality in patients presenting with suspected cerebral infection. In cerebral toxoplasmosis, additional head MRI is performed to illustrate the lesion most clearly. However, MRI is expensive, time-consuming, and require significant patient cooperation, hence in cases where MRI is limited, diagnosis of cerebral toxoplasmosis with $\mathrm{CT}$ images is sufficien. ${ }^{7}$

In the CNS, tachyzoite infects astrocytes, neurons, microglia with varying affinity. Parasitic infiltration is then followed by an influx of CD4+ and CD8+ to control the extent of $T$. gondii infection and releases inflammatory cytokines. This can result in direct and/or indirect effects in the CNS illustrated in brain imaging findings characteristic for cerebral toxoplasmosis. Direct effects are caused by direct interaction between the parasite and effector proteins or remaining in host neuron, inducing changes in the physiology of neurotransmitter. Indirect effects arise from CNS immune response which decreases in controlling the infection. ${ }^{8,9}$

HIV/AIDS patients have many differential diagnoses of co-infection with CNS involvement. Previous study in Bangkok, Thailand showed that frequently found are HIV encephalopathy (59.1\%), cerebral toxoplasmosis $(21.8 \%)$, tuberculous (TB) meningitis or tuberculoma $(9.2 \%)$, cryptoccoma $(8.8 \%)$, progressive multifocal leukoencephalopathy (3.1\%), and lymphoma (2.1\%). They found that cerebral toxoplasmosis lesion is most frequently multiple ring or nodular enhancement at corticomedullary junction and basal ganglia with surrounding edema and mass effect. This lesion type and location can serve as a reference in making the diagnosis and excluding the differential diagnoses of brain lesions in patients with HIV/ AIDS. Cryptoccoma lesion is hypodense, multifocal, nonenhancing at basal ganglia and midbrain which represents the gelatinous pseudocyst and the presence of dilated perivascular space. Leptomeningeal enhancement can also be found. Progressive multifocal leukoencephalopathy also shows hypodense non-enhancing lesion without mass effect, commonly at the parietal and occipital lobes while lymphoma is more easily differentiated from toxoplasmosis because it commonly presents as hyperdense homogenous, heterogenous, or forming a ring-like pattern 
at the periventricular white matter, basal ganglia, corpus callosum, and thalamus. CT image of HIV encephalopathy shows brain atrophy which is multifocal hypodense deep white matter and clinically proven with symptoms of dementia. ${ }^{10}$

TB meningitis or tuberculoma is the most difficult to differentiate with cerebral toxoplasmosis. Tuberculoma most commonly presents as ring/nodular enhancement with perilesion edema. Target sign can also be found in TB meningitis, seen as a rim-enhancing lesion with an area of central enhancement or calcification. However, if only ring-enhancement were found, it is difficult to differentiate between TB meningitis and cerebral toxoplasmosis and hence the patient's history of TB has to be considered. CNS TB is usually caused by hematogenous spread of bacteria and focal spread from intracranial or extracranial sources is rare. In TB meningitis, isodense or slight hyperdense enhancing exudates at basal cysterna is the most common finding and relatively specific in TB leptomeningeal enhancement. Meningeal enhancement is found in $90 \%$ cases and is the most sensitive finding of TB meningitis. Exudate is commonly found at the surface of the anteromedial temporal lobe, superior cerebellum, and the $3^{\text {rd }}$ ventricle. In most cases, there may be some degree of meningeal involvement in the cerebral sulcus and ventricular fissure. ${ }^{11}$ Other characteristic head CT lesions that can be found are leptomeningeal enhancement at basal cysterna and communicating hydrocephalus. Similar to the findings in this study, leptomeningeal enhancement is found in 3 patients with CD $4<200$, none in CD4 $>200$, and 3 in patients without CD4 data. Overall, the majority of patients do not have the abnormality of leptomeningeal enhancement and gyral enhancement or hydrocephalus.

In total, post-therapeutic results of HIV/AIDS patients with suspected cerebral toxoplasmosis is the recovery in $68.9 \%$ of patients. This shows that the majority of patients have improved clinical conditions after treatment with empirical anti-toxoplasmosis. No recovery is found in $31.4 \%$ of patients in this study, similar to a study in Malaysia with a mortality rate of $31.6 \%$, mostly in patients with acute cerebral toxoplasmosis which is also associated with their systemic illnesses. ${ }^{12}$ In this study, $42.9 \%$ of patients have comorbidities such as maxillary, ethmoidal, sphenoidal, frontal sinusitis, and sinus retention cyst.

Limitation of this study is the number of samples obtained. Further studies with more samples and variables are required to achieve a more representative result. However, studies on head CT images of cerebral toxoplasmosis in HIV/AIDS patients are still rarely conducted. Findings from this study add more knowledge on CT characteristics of cerebral toxoplasmosis, especially associated with their therapeutic response.

\section{Conclusion}

Characteristic head CT images of HIV/AIDS patients with suspected cerebral toxoplasmosis is multiple, hypodense with slight rim contrast enhancement, and located at cortical. Slight variations are found in patients with higher CD4 count. Patients with lesion diameter $<1 \mathrm{~cm}$ generally have a good success rate in empirical anti-toxoplasmosis. Additional problems found in the head CT images include leptomeningeal and gyral enhancement.

\section{Conflict of Interest}

The author stated there is no conflict of interest

\section{References}

1. Muluye D, Wondimeneh Y, Belyhun Y, et al. Prevalence of Toxoplasma gondii and Associated Risk Factors Among People Living with HIV at Gondar University Hospital, Northwest Ethiopia. ISRN Tropical Medicine. 2013; 2013.

2. Wang Z-D, Liu H-H, Ma Z-X, et al. Toxoplasma gondii Infection in Immunocompromised Patients: a Systematic Review and Metaanalysis. Frontiers in Microbiology. 2017; 8: 389

3. Rumboldt Z, Castillo M, Huang B and Rossi A. Brain Imaging with MRI and CT: An Image Pattern Approach. Cambridge University Press, 2012.

4. Sriwidyani NP. Cerebral Toxoplasmosis in Aid Patient A Case Report and Review Literature. International Journal of Science and Research. 2017: 1445-7.

5. Nissapatorn V, Lee C, Quek KF, Leong CL, Mahmud R and Abdullah KA. Toxoplasmosis in HIV/AIDS Patients: A Current Situation. Japanese Journal of Infectious Diseases. 2004; 57: 160-5.

6. Ambrosioni J, Alvarez-Martínez MJ, Berenguer J and Miró JM. Toxoplasmosis in HIV-Infected Patients. Encyclopedia of AIDS. 2014: 1-14.

7. Kastrup O, Wanke I and Maschke M. Neuroimaging of Infections. NeuroRx. 2005; 2: 324-32.

8. Mendez OA and Koshy AA. Toxoplasma gondii: Entry, Association, and Physiological Influence on the Central Nervous System. PLoS Pathogens. 2017; 13: e1006351.

9. Kamerkar S and Davis PH. Toxoplasma on the Brain: Understanding Host Pathogen Interactions in Chronic CNS Infection. Journal of Parasitology Research. 2012; 2012.

10. Hongsakul K and Laothamatas J. Computer Tomographic Findings of the Brain in HIV Patients at Ramathibodi Hospital. Medical journal of the Medical Association of Thailand. 2008; 91: 895.

11. Sanei Taheri M, Karimi MA, Haghighatkhah H, Pourghorban R, Samadian M and Delavar Kasmaei H. Central Nervous System Tuberculosis: An Imaging Focused Review of a Reemerging Disease. Radiology Research and Practice. 2015; 2015.

12. Nissapatorn V, Lee C, Cho S, et al. Toxoplasmosis in HIV/AIDS patients in Malaysia. Southeast Asian Journal of Tropical Medicine and Public Health. 2003; 57: 18.9. 